\title{
Three new miospore genera from the Lower Carboniferous (Viséan) rocks of east Fife, Scotland
}

\author{
RICHARD S. W. NEVILLE \\ The Robertson Group plc, Llandudno. Gwynedd. North Wales LL30 1SA.
}

\begin{abstract}
Three new miospore genera, Dillspora, Oswaldispora and Robandispora are described from the Lower Carboniferous (Viséan) rocks of east Fife. One new species. Robandispora claytonii is erected. Two new combinations, Dillspora disjuncta and Oswaldispora xenika, are proposed and the diagnosis of the latter is emended.
\end{abstract}

\section{INTRODUCTION}

The author, in Neves et al. (1973), described two new miospore taxa under the species names disjuncta and xenika, which were tentatively assigned to the genus Rotaspora. Subsequent study has led to the consideration of these forms as belonging to two new miospore genera, named here as Dillspora gen. nov. and Oswaldispora gen. nov. respectively. The species formerly designated as? Rotaspora xenika is emended. The type species of the newly proposed genera are therefore Dillspora (?Rotaspora) disjuncta Neville in Neves et al. (1973) comb. nov. and Oswaldispora (?Rotaspora) xenika Neville in Neves et al. (1973) comb. nov. emend. In the author's Ph.D thesis (1969) a further new species, not previously published, was described which was tentatively placed in the genus Pteroretis, Felix \& Burbridge (1961). This form is now considered to be a distinctive new genus, named here as Robandispora gen. nov., and the type species, also described in this paper, is designated Robandispora claytonii sp. nov.

The three species referred to above are all morphologically distinct and none can justifiably be assigned to any existing genus. For this reason it has been considered necessary to erect three new genera to accommodate them, even though each is, as yet, monospecific.

For the stratigraphy of the area and the location of the samples discussed, reference should be made to Neves et al. (ibid, p.25-26 and text figures 1-4). All holotypes and other figured specimens of the three new genera are housed in the micropalaeontology collection of the Centre for Palynological Studies of the University of Sheffield. The number prefixed by ' $M L$ ' is the collection reference number and the second set of figures indicates the sample horizon/slide number. The final numbers, in brackets, are the England finder coordinates.

\section{SYSTEMATIC DESCRIPTIONS}

Anteturma Sporites H. Potonié, 1893

Turma Triletes (Reinsch) Dettmann. 1963

Suprasubturma Acameratitrilites Neves and Owens, 1966

Subturma Zonotriletes Waltz, 1935

Infraturma Cingulati (Potonié and Klaus)

Dettmann, 1963

Genus Dillspora gen. nov.

Type species. Dillspora (?Rotaspora) disjuncta Neville in Neves et al. (1973) comb. nov.

Derivation of name. For my mother Alice Mona (Dill) Neville.

Diagnosis. Miospores radial; trilete. Suturae simple or labrate. Spore body circular to triangular. Proximal surface laevigate, although it may show variations in exine thickness. The distal surface possesses either a thickened polar boss and sub-polar thickened ring, both of which may be variably developed and even connected, or the ornament may be limited to irregular rugulae. There is an equatorial extension of the exine which is widest interradially, being reduced or absent at the apices. It may contain invaginations and is laevigate, apart from the distal sculpture which may extend on to it.

Remarks. The combination of interradial extensions of the exine and type of distal sculpture serves to distinguish the genus. Further research may show that forms with proximal ornament also exist.

Comparison. Annulispora (De Jersey) emend. McKellar (1974), Knoxisporites (Potonié \& Kremp) emend. Neves (1961), Polycingulatisporites (Simoncsics \& Kedves) emend. Morbey (1975) and Taurocusporites (Stover) emend. Playford \& Dettmann (1965) all differ in various aspects, but mainly in lacking an equatorial feature which is widest interradially. Coronatispora Dettmann (1963) possesses foveolate to reticulate sculpture. Camarozonosporites Pant (1954 ex Potonié, 1956) emend. Klaus (1960) lacks most of the sculptural 
elements typical of Dillspora. The end members of the latter, which possess only rugulae on the distal surface, may possibly fall within the circumscription of the genus Camarozonosporites. However, Camarozonosporites was originally described from Cretaceous rocks and the stratigraphic separation and distinctly different morphological variation are therefore considered sufficient to separate the genera. Camarozonotriletes Naumova (1939 ex Ishchenko, 1952) emend. Potonié (1958) possesses a sculptured equatorial extension and hence irregular margin. Rotaspora (Scheme1) emend. Smith and Butterworth (1967) possesses only simple laesurae and has different sculpture, being laevigate to verrucate. In addition the type species of Rotaspora (R. fracta Schemel, 1950) appears structurally different from other species attributed to the genus, the equatorial feature seeming to overlap on to the proximal surface at the apices. Dillspora may superficially resemble Knoxisporites stephanephorus Love (1960) but differs by possessing an equatorial extension which is reduced or absent at the apices.

Dillspora disjuncta comb. nov.

(PI. 1, figs. 1-4)

1973 ?Rotaspora disjuncta, Neville in Neves et al., $37-38$, pl. 1, figs. $22-23$.

Remarks. See genus.

Stratigraphic distribution. Samples F41-F95 and RA1: Concurrent Range Zones TC, NM and VF, Lower Carboniferous, Asbian - Brigantian.

Genus Oswaldispora gen. nov.

Type species. Oswaldispora (?Rotaspora) xenika (Neville in Neves et al., 1973) comb. nov. emend. Derivation of name. For my late father Oswald William Neville.
Diagnosis. Miospores radial; trilete. Suturae labrate. Spore body circular to triangular. Exine ornamented with irregular rugulae which may be simple, anastomose and terminate freely or delimit irregular lumina. In addition there may be coni and/or verrucae. The ornament is generally coarser on the distal surface and the proximal surface may be laevigate, especially in the polar region. There is an equatorial extension of the exine which is laevigate or infrapunctate and is widest interadially, being reduced or absent at and near the apices. Other invaginations may be present. High distal pole.

Remarks. The high distal pole means that on polar or sub-polar compression the distal surface projects beyond the ends of the suturae and also makes the equatorial extension of the exine appear as if it is located on the proximal surface. The combination of interradial extensions of the exine, the type of ornament and the high distal pole, serves to distinguish this genus.

Comparison. Camarozonosporites Pant (1954 ex Potonié, 1956) emend. Klaus (1960), Camarozonotriletes Naumova (1939 ex Ishchenko, 1952) and Rotaspora (Schemel) emend. Smith and Butterworth (1967) all lack the typical ornament and high distal pole of Oswaldispora gen. nov. Coronatispora Dettmann (1963) lacks the high distal pole and possesses foveolate to reticulate sculpture.

Oswaldispora xenika comb. nov. emend.

(PI. 1, figs. 5-6)

1960 Spore type 3, Love, p.123, pl. 2, figs. 11-12 and text-fig. 14.

1973 ?Rotaspora xenika, Neville in Neves et al., p.38 and pl. 1, figs. 26-27.

\section{Explanation of Plate 1}

Figs. 1-4. Dillspora disjuncta comb. nov. $(\times 1000)$.

Fig. 1. Holotype, polar compression, focused on equator; ML898, F66/8 (P24).

Fig. 2. Holotype, polar compression, focused on distal boss and annulus; ML898, F66/8 (P24).

Fig. 3. Paratype, oblique polar compression; ML898, F66/8 (E15).

Fig. 4. Oblique polar compression. Note the interradial invagination in the equatorial structure; ML748, F94/1 (S21).

Figs. 5-6. Oswaldispora xenika comb. nov. emend. $(\times 1000)$.

Fig. 5. Holotype, polar compression focused on proximal surface; ML900, A11/5 (U34).

Fig. 6. Paratype, oblique polar compression. Note the equatorial structure pulled over on to the proximal surface by a sutura; ML901, RA34/2 (G14/4).

Figs. 7-9. Robandispora claytonii gen. et sp. nov. $(\times 750)$.

Fig. 7. Paratype, slightly oblique polar compression showing trilete mark and radiating ribs; ML1792, F79/3 (F58/3).

Fig. 8. Holotype, slightly oblique polar compression showing trilete mark and lobate flanges with concentric ribs; ML1793, F79/4 (E27/4).

Fig. 9. Slightly oblique polar compression showing labra and radiating ribs; ML1794, F79/5 (J59/4). 

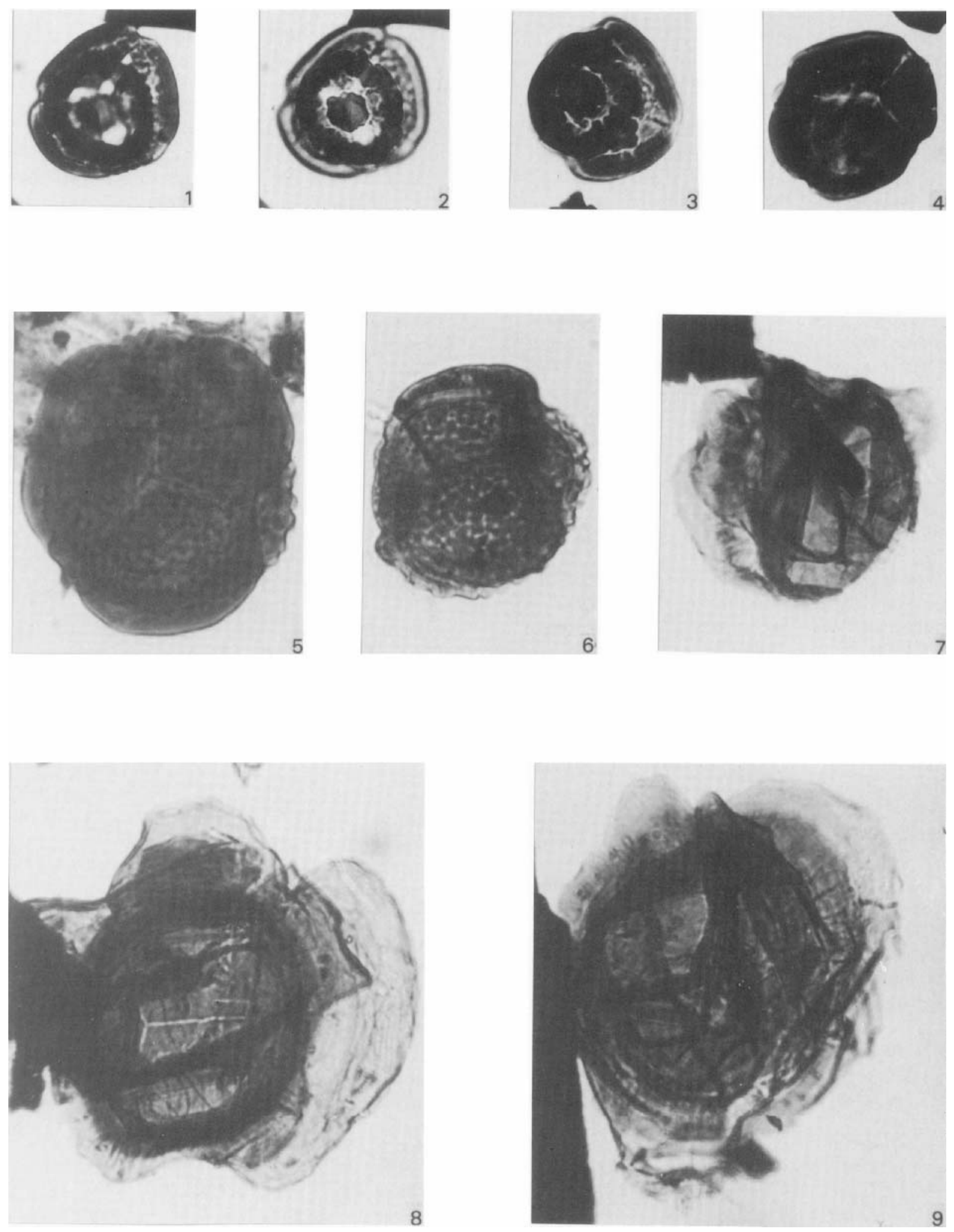
Emended diagnosis. Miospores radial, trilete. suturae straight. extending $\frac{1}{2} / \frac{z}{3}$ of the spore body radius and accompanied by narrow raised labra. Amb of spore body subcircular to broadly rounded triangular. Exine ornamented with irregular rugulae which may be simple but they usually anastomose and terminate freely and may delimit irregular lumina. In addition there may be coni and/or verrucae. The ornament is generally coarser on the distal surface and in the proximal polar region it may be absent. There is an equatorial extension of the exine which is laevigate or slightly infrapunctate and is widest interradially, being reduced or absent at and near the apices. Other invaginations may be present. High distal pole.

Type locality and horizon. East Fife coast. Sample All: $4^{\prime \prime}$ coal at a depth of $306^{\prime} 6^{\prime \prime}$ in the Anstruther Borehole. Description. Holotype, overall size $57 \mu$. spore body broadly rounded triangular. $46 \mu$. Suturae straight. extending about $\frac{1}{2}$ spore body radius and accompanied by narrow raised labra. Exine ornamented with densely packed irregular rugulae which anastomose and terminate freely. occasionally delimiting lumina. In addition there are a few coni and verrucae. The ornament is coarser over the distal surface, being absent in the proximal polar region. At the apices the ornament projects up to $1.5 \mu$ beyond the spore margin. There is a laevigate equatorial extension of the exine which is widest interradially $(9 \mu)$ and much reduced or absent at and near the apices. On compression. due to the high distal pole. the base of this extension appears to be inset up to $5 \mu$ from the spore body margin on the proximal surface.

Dimensions. Diameter of spore body $29 \mu(40 \mu) 54 \mu$ based on 13 measured specimens. Exine up to $3.5 \mu$ thick.

Remarks. This species has been emended to take into account the high distal pole. This means that the extension of the exine is equatorial in position and only appears to be situated on the proximal surface, as originally described by the author. due to compression (pl. 1, figs. 5-6). This extension is up to $13 \mu$ wide and may appear inset on the proximal surface up to $6 \mu$ from the spore edge by compression on specimens so far observed. In pl. 1. fig. 6 the equatorial extension of the exine is pulled across on to the proximal surface by a sutura at one of the apices.

Stratigraphic distribution. Samples F37-F53, A25. RA34, RA75 and WS7: Concurrent Range Zones TC and NM (Subzone DP): Lower Carboniferous. Asbian.

Suprasubturma Cameratitriletes Neves and Owens. 1966

Subturma Membranatitriletes Neves and Owens. 1966

Genus Robandispora gen. nov.
Type species. Robandispora claytonii sp. nov. Derivation of name. For my two sons Robert and Andrew.

Diagnosis. Miospores radial; trilete. Outline subcircular to extremely irregular. Spore body, formed by the intexine, circular to subcircular. usually folded and either laevigate or sculptured. Suturae straight, simple or partially or completely labrate. The thin laevigate exoexine is closely adpressed to the intexine over most of both surfaces. Near the equator on the proximal surface there is an extension of the exoexine into a membrane with radiating ribs, which extends beyond the margin of the intexine. Close to the equator on the distal surface there are series of extensions of the exoexine into flanges which may at least partially overlap.

Remarks. A very complicated morphology which, although being distinctive, has a structure which is not yet fully understood.

Comparison. The only genus, so far described, which bears any resemblance to Robandispora gen. nov. is Pteroretis, Felix and Burbridge (1961). The latter, however, possesses six membranous wings which run from pole to pole and lacks the extensions of the exoexine characteristic of Robandispora gen. nov.

\section{Robandispora claytonii sp. nov.}

Derivation of name. For Dr. G. Clayton, in recognition of his valuable work in Lower Carboniferous palynology.

Diagnosis. Miospores radial, trilete; amb subcircular to extremely irregular. The spore body is circular to subcircular and is either laevigate or possesses a few small coni projecting from the equator. The spore body (intexine) is usually folded, often intensely. The suturae are straight and extend about $\frac{2}{3} / \frac{3}{4}$ of the body radius and are either simple or partially or completely labrate. The thin laevigate exoexine is closely adpressed to the intexine over most of both surfaces and may be wrinkled. Near to the equator on the proximal surface there is an extension of the exoexine into a membrane with radiating ribs which extends beyond the margin of the intexine. Close to the equator on the distal surface there are series of extensions of the exoexine into flanges which may at least partially overlap. They are usually deeply incised and lobate and may be laevigate, wrinkled or sculptured with concentrically or subconcentrically arranged ribs which may anastomose.

Holotype. Pl. 1, fig. 8. Preparation ML1793, F79/4 (E27/4).

Paratype. Pl. 1, fig. 7. ML1792, F79/3 (F58/3).

Type locality and horizon. East Fife coast. Sample F79; $5^{\prime \prime}$ coaly scale $190^{\prime}$ below the West Braes Marine Band exposed on the coast between Pathhead and Sandy 
Craig just west of Pittenweem.

Description. Holotype, overall size $92 \mu$, spore body $63 \mu$. Amb deeply incised and lobate. Spore body subcircular, folded, with an exine about $1 \mu$ thick which bears a few coni, up to $1 \mu$ in height, projecting at the equator. Suturae simple, straight, extending $\frac{2}{3}$ of the spore body radius. The thin laevigate exoexine is closely adpressed to the intexine over most of both surfaces and bears a few wrinkles. Inset about $4-5 \mu$ from the spore body equator on the proximal surface there is the base of an extension of the exoexine into a membrane which extends about $7-8 \mu$ beyond the spore body margin and possesses fine radiating ribs which are denser towards the base. From near the equator on the distal surface there arise at least two series of lobate extensions of the exoexine into flanges which overlap each other to various degrees and extend up to $26 \mu$ beyond the spore body margin. They possess concentrically or subconcentrically arranged ribs of variable density which may anastomose.

Dimensions. Overall $56-97 \mu$, spore body diameter $42-64 \mu$. Measurements based on 15 specimens from the type locality.

Stratigraphic distribution. Samples F79 and F95 (one specimen): Concurrent Range Zone VF; Lower Carboniferous, Brigantian.

\section{ACKNOWLEDGEMENTS}

The author would like to thank the Centre for Palynological Studies, University of Sheffield for lending him the relevant slides from his thesis material and also for providing him with additional sample material for further palynological preparations. He is grateful to Dr. R. Neves, Dr. J. P. G. Fenton and Miss B. E. Rich for kindly reading the manuscript and making constructive criticisms. Finally, he would like to thank the directors of The Robertson Group plc for the use of their typing and photographic facilities and also for permission to publish.

Manuscript received July 1988

Revised manuscript accepted February 1989

\section{REFERENCES}

Clayton, G., Higgs, K., Keegan, J. B. \& Sevastopulo, G. D., 1978. Correlation of the palynological zonation of the Dinantian of the British Isles. Palinologia, 1, 137-147.

De Jersey, N. J., 1959. Jurassic spores and pollen grains from the Rosewood Coalfield. Queensland Govt. Mining J., 60, 344-366.

Dettmann, M. E., 1963. Upper Mesozoic microfloras from south-eastern Australia. Proc. Roy. Soc. Victoria, 77, $1-148$.

George, T. N., Johnson, G. A. L., Mitchell, M., Prentice, J. E., Ramsbottom, W. H. C., Sevastopulo, G. D. \& Wilson, R. B. 1976. A correlation of Dinantian rocks in the British Isles. Geol. Soc. Lond., Special Report 7, 1-87.
Felix, C. J. \& Burbridge, P. P., 1961. Pteroretis, a new Mississippian spore genus. Micropaleontology, 7, 491-495.

Ishchenko, A. M., 1952. Atlas of microspores and pollen of the Middle Carboniferous period in the western part of the Donets Basin. Tr. Inst. Geol. Nauk. Akad. Nauk Ukr. R.S.R., 1-83 [in Russian].

Klaus, W., 1960. Sporen des karnischen Stufe der ostalpinen Trias. Jahrb. Geol. Bundesanstalt (Austria), 5, 107-183.

Love, L. G., 1960. Assemblages of small spores from the Lower Oil Shale Group of Scotland. Proc. Roy. Soc. Edinburgh, 67(2), 99-126.

McKellar, J. L., 1974. Jurassic miospores from the upper Evergreen Formation Hutton Sandstone and basal Injune Creek Group, north-eastern Surat Basin. Geol. Surv. Queensland, Publ. 361, Palaeont. Paper 35, 1-89.

Morbey, S. J., 1975. The palynostratigraphy of the Rhaetian Stage, Upper Triassic in the Kendelbachgraben, Austria. Palaeontographica, $B, \mathbf{1 5 2}, 1-75$.

Naumova, S. N., 1939. Spores et pollen des houilles d'U.R.S.S. Tr. 17. Sessii Mezhdunarvdn. Geol. Kongressa S.S.S.R., 1937g., 1, 355-366 [In Russian). (Intern. Geol. Congr., 17th Moscow, Rept.).

Neves, R., 1961. Namurian plant spores from the southern Pennines, England. Palaeontology, 4(2), 247-279.

Neves, R., Gueinn, K. J., Clayton, G., Ioannides, N. S., Neville, R. S. W. \& Kruszewska, K., 1973. Palynological Correlations within the Lower Carboniferous of Scotland and Northern England. Trans. Roy. Soc. Edinb. 69, No. 2, $23-70$.

Neville, R. S. W., 1969. The stratigraphic distribution of miospores in the Lower Carboniferous of east Fife, Scotland. Unpublished Ph.D. thesis, University of Sheffield, $1-330$.

Pant, D. D., 1954. Suggestions for the classification and nomenclature of fossil spores and pollen grains. Botan. Rev., 20, 33-60.

Playford, G. \& Dettmann, M. E., 1965. Rhaeto-Liassic plant microfossils from the Leigh Creek Coal Measures, South Australia. Senck. Leth., 46, 2/3, 127-181.

Potonié, R., 1956. Synopsis der Gattungen der Sporae dispersae, 1. Geol Jahrb., Beih., 23, 3-103.

Potonié, R., 1958. Synopsis der Gattungen der Sporae dispersae, 2. Geol. Jahrb., Beih., 31, 3-114.

Schemel, M. P., 1950. Carboniferous plant spores from Daggett County, Utah. J. Paleontol., 24, 232-244.

Smith, A. H. V. \& Butterworth, M. A., 1967. Miospores in the coal seams of the Carboniferous of Great Britain. Special Papers in Palaeontology, 1, London, 1-324. 